Варламов А. Н.

Аннотация. Целью исследования является подтверждение научного тезиса о сохранении древних знаний об эволюции сибирского ландшафта в мировоззренческих традициях и устном народном творчестве коренных народов Сибири. Научная новизна исследования заключается в междисциплинарном анализе этимологической интерпретации содержания обрядового запева, суть которого сводится к описанию последовательных этапов эволюции сибирского ландшафта на рубеже и в начале голоцена. В результате доказано, что в фольклорных и мировоззренческих традициях эвенков отчетливо просматриваются реликтовые формы знаний древних сообществ об эволюции сибирского ландшафта и человеческого общества на стадии приобретения признаков этнической культуры.

\title{
EN Representations of Siberian Landscape Evolution in the Evenk Ikenipke Ritual
}

\author{
Varlamov A. N.
}

\begin{abstract}
The paper justifies the thesis that Siberian people's folklore and oral traditions represent the ancient knowledge on Siberian landscape evolution. Scientific originality of the research involves the interdisciplinary approach to studying historical content of a ritual chant describing the stages of Siberian landscape evolution in the early Holocene Epoch. As a result, it is proved that Evenk ritual folklore visibly represents the ancient knowledge on evolution of society and nature in the period of ethnic culture formation.
\end{abstract}

\section{Введение}

В исследовании предпринимается попытка представления древних знаний о ранних этапах истории Сибири на примере традиций обрядового фольклора эвенков. С одной стороны, данная мера необходима для наглядной демонстрации исторического потенциала устного народного творчества, с другой - чтобы обозначить перспективы междисциплинарного подхода к изучению устного народного творчества тунгусоманьчжурских народов и фольклора как культурного явления в целом. Актуальность настоящей публикации определяется ростом значения междисциплинарного подхода в исследованиях различных жанров устного народного творчества.

Для достижения поставленной цели решаются следующие задачи: определение этимологии запевных строк обрядового текста; поиск культурных параллелей в этнографических традициях тунгусо-маньчжурских народов и истории Сибири; построение последовательной структуры эволюционной модели развития этнической культуры во взаимосвязи с изменением сибирского ландшафта.

Для решения задач избран метод комплексного подхода к изучению проблем соотношения фольклора и истории. В рамках данного метода традиции устного народного творчества эвенков рассмотрены с точки зрения истории, лингвистики, этнографии и смежных научных дисциплин, что позволяет обеспечить объективный взгляд, новизну и результативность исследования.

Теоретической базой исследования послужили работы Н. И. Надеждина [21], Л. Н. Гумилева [11], в которых авторы обозначили перспективность научного взгляда на историю этноса во взаимосвязи с ландшафтом, питающим культурные традиции. Работа выполнена в соответствии с теоретическими положениями о типологии фольклорного историзма, разработанными отечественными исследователями фольклора: Е. М. Мелетинским [19; 20], В. Я. Проппом [27; 28], Б. Н. Путиловым [29; 30] и др.

При подготовке публикации привлекались работы Г. М. Василевич [5-7], Т. Ю. Сем [31], посвященные теме исследования. Кроме этого, были привлечены результаты исследований по палеогеографии, палеогеологии, палеогенетике и истории. 
Основными материалами для исследования послужили опубликованные тексты устного народного творчества, изданный словарный фонд тунгусо-маньчжурских языков, а также описание мировоззренческих и шаманских традиций эвенков в этнографических исследованиях.

Практическая значимость исследования заключается в возможности использования его результатов в процессе преподавания вузовских курсов по истории устного народного творчества, как культурного явления, и по истории народов тунгусо-маньчжурской группы.

\section{Основная часть}

Тема соотношения истории и фольклора остается актуальной в отечественной и зарубежной фольклористике в течение длительного времени. Историзм является органическим свойством устного народного творчества: «История и фольклор представляют собой органическое целое и могут быть поняты только лишь друг через друга» [22, с. 51].

Изучение проблем фольклорного историзма актуально для бесписьменных и младописьменных народов, фольклорные традиции которых наиболее тесно связаны с понятием «неписанная история». Обращение к фольклору бесписьменных народов связано «с открытием все новых возможностей художественного познания истории, то есть в конечном счете с развитием народного осмысления исторической действительности и с расширением народного исторического опыта» [29, с. 167]. В архаическом фольклоре функциональные связи с бытом и этнической историей проступают явственнее, что определяется высокой степенью инклюзивности - вовлеченности всей фольклорной культуры, отдельных конкретных ее слагаемых в систему жизнедеятельности этноса $[28$, с. 59, 73]. Исторические корни фольклора восходят к глубокой древности, что «обусловлено непрерывностью фольклорной традиции, восходящей к самым ранним ступеням племенной истории, сохранением значительных пережитков родового строя в быту и общественном сознании» [20, с. 1].

На протяжении тысячелетий фольклор являлся своеобразной художественной формой передачи разнообразной информации, в том числе исторического характера, на что обращали внимание исследователи древней истории в рамках археологических изысканий. По мнению Дж. Фьюкса, любое изучение археологических памятников неизбежно влечет за собой изучение современного фольклора [39]. Схожее мнение выражали ведущие отечественные специалисты по древней истории народов Сибири. А. П. Окладников в реконструкциях культурных традиций населения прибайкальского неолита неоднократно отмечал отчетливые культурные параллели с этнографическим комплексом тунгусов, обнаруживая их в эвенкийском фольклоре. Например, сюжеты эвенкийских мифов о завещании частей тела медведем использовались А. П. Окладниковым для реконструкции традиций древнего похоронного обряда [23, с. 408-409]. Сюжеты эвенкийской мифологии и шаманские традиции эвенков неоднократно привлекались А. П. Окладниковым и А. И. Мазиным в работах, посвященных наскальной живописи сибирского неолита $[17$, с. 8,23 ; 24, с. 82; 25, с. 93, 95, 116-117] и др.

На современном этапе развития науки тема соотношения истории и фольклора приобретает значительные перспективы для исследования. Современные исследования указывают на фольклор как на специфическую систему хранения культурной информации разных периодов этнической истории, истоки которой уходят в поздний палеолит [9; 12]. Междисциплинарный подход к проблематике фольклорного историзма позволяет привлекать результаты современных исследований в самых разных специальностях научной сферы.

Эвенкийский фольклор и эвенкийские традиции мировоззрения донесли до нашего времени знания древних сообществ об эволюции сибирского ландшафта. Рассмотрим подробно данный тезис на примере шаманских традиций эвенков. Описывая эвенкийский обряд Икэнипкэ, Г. М. Василевич опубликовала древний обрядовый текст, повествующий о стадиях зарождения земли, формирования современного ландшафта Сибири, с которым, начиная с эпохи позднего каменного века, была неразрывно связана судьба далеких предков современных тунгусов. В первый день восьмидневного обряда-камлания Икэнипкэ существовала традиция коллективного исполнения обрядового запева, повествующего о стадиях становления земли:

«Пагэй-пагэй!

Кулур-кулур!

Декур-декур!

Дуннэр-дуннэр!

Химир-химир!

Уюр-уюр!

Токур-токур!

Аба-аба!

Дэрэ-дэрэ!

Слова эти в современном эвенкийском языке отсутствуют; эвенки пытались толковать их как названия различных стадий становления земли» [5, с. 157-158]. Действительно, весьма сложно интерпретировать значение слов приведенного запева, т.к. в нем используются устаревшие формы эвенкийского языка, сохранившиеся в редких случаях в музыкальном фольклоре (запевы круговых танцев), обрядовой культуре и в некоторых запевах героев сказаний эвенков.

По мнению Т. Ю. Сем, этот обрядовый запев содержит описание различных последовательных стадий эволюции земли: «Из текста следует, что образование земли прошло 9 стадий. Вода рванулась с места, побежала и стала убывать, появилась суша. В результате шевеления образовалась длинная гряда гор. Произошел пожар, и появились земля, гора и тайга, болота, поверхность земли. Возможно, также отображен сюжет о полете 
птицы творения. Однако последний сюжет четко не прочитывается и не перекрещивается с понятием о поверхности земли» [31, с. 105]. На основе лингвистического анализа исследователь представила следующую интерпретацию запевных строк: «Слово пагэй означает: вода начинает убывать, суша. Кулур - шевельнуться, образоваться длинным хребтам, горам, окаменелостям. Декур - пожар, огонь (весь день). Дуннэр - земля, тайга. Химир - хребты, волнистый. Утор - тундра, болота. Токур - крутиться, дым, птица, подниматься или от тукала - ил (в нанайском токала - земля). Аба - тайга, степь, открытое место. Дэрэ - лицо (вероятно, связано с названием Венеры, где возрождаются души людей, или это поверхность земли)» [Там же, с. 105]. Т. Ю. Сем правомерно обозначила содержание запева в целом как описание эволюционного развития планеты, однако, по нашему мнению, запев связан непосредственно с историей Сибири, а содержание некоторых запевных строк имеет иное значение.

Представим собственную трактовку этимологического значения запевных строк. Первая запевная строка: Пагэй-пагэй - исходя из лингвистического анализа тунгусо-маньчжурских языков, корень Паг-Пэг зафиксирован в нескольких тунгусо-маньчжурских языках и имеет звукоподражательное происхождение, связанное с выстрелом, звуком взрыва. В эвенкийском языке производные от корня паг, пэг означают: «звук выстрела», «стрелять, стрельба, оружие, хлопнуть» и др. [36, с. 483-484], а также «разорвать, порваться, лопнуть». В эвенском языке корень пэк, пок образует множество схожих слов: выстрел, стрельба и др. производные слова. В негидальском: зажигать, стрелять, оружие, выстрел. В удэгейском: хлопать, щелкать (о выстреле), сильный хлопок. В маньчжурском языке: звук выстрела, взрыва [34, с. 32, 45, 46]. Отметим, что слова с корнем паг/пэг не относятся к позднему лексическому пласту тунгусо-маньчжурских языков, связанному с началом использования огнестрельного оружия, т.к. слова с подобным корнем взаимосвязаны со стрельбой из лука и другими резонирующими звуками, например со звучанием варгана [37, с. 338]. Кроме этого, присутствие единого лексического значения во всех языках тунгусо-маньчжурской группы свидетельствует в пользу того, что слова от корня паг/пэг возникли в языке прототунгусов (в эпоху древне-тунгусской общности) задолго до появления огнестрельного оружия.

По нашему мнению, представленная выше строка запева содержит историческую память о каком-либо крупном историческом явлении, сопряженном с тектоническими процессами, либо с падением крупного космического объекта, что повлекло глобальные изменения сибирского ландшафта. Локальные фольклорные традиции позволяют обозначить подобную взаимосвязь с историей Сибири, в частности с историческим процессом возникновения Байкала:

«Давно, наверное, это было, так давно, что много миллионов лет прошло с тех пор... Но случилось, говорят, это так: свалился на землю громадный камень, ну как теперь сваливаются, только сейчас они маленькими падают. Упал тот камень около Саян. Пока он падал на землю, раскалился, а когда упал, то пошел проливной дождь. В воронку на горячий камень потекла вода - все вскипело. Кругом начали растопляться снега и льды... А мой дедушка рассказывал, что Байкал произошел от того, что в том месте шибко большая молния ударила и прорезала землю до самой подземной воды. Та вода потом затопила много падей и гор, а потом и море стало» [1, с. 35];

«Много тысяч лет назад, а может, и миллион прошло, когда у гор, где ныне Байкал, появились люди. Те люди были не такие как теперь, им не надо было одежду, они ходили обросшими волосами, и оттого им было тепло. Жили те люди в скалах, там они себе устроили такие места для жилья, где можно было по сотне человек жить... Так и жили люди до поры до времени. Потом на глазах людей земля заходила под ногами, и из-под земли донесся страшный гром, горы и скалы зашатались, деревья попадали... Через некоторое время солнце начало так палить, что снега и скалы льда затаяли. Вода просто рекой полилась к тому месту, где была глубокая трещина в земле... Вот так-то наш Байкал появился» [38, с. 252-253].

Современные исследования отмечают решающую роль природно-климатических, тектонических процессов в эволюции сибирского ландшафта. Особенно отчетливо это проявляется в исследованиях байкальского ландшафта, результаты которых демонстрируют сильнейшую активизацию сейсмичности в конце плейстоцена начале голоцена. Палеосейсмологами обнаружены свидетельства о двух сильнейших землетрясениях, произошедших 8-10 тыс. и 12-14 тыс. лет назад [35, с. 17-18]. Эти относительно недавние в историческом измерении события вполне могли найти отражение в фольклорных повествованиях и шаманском запеве эвенков.

Запевная строка Кулур-кулур, по всей вероятности, связана со словами от корня кул, символизирующими понятие «далекое прошлое», «вечность», «постоянство». В эвенкийском языке глагол кул-ми означает «пройти давно», «отдаляться во времени», «быть в прошлом» [36, с. 311]. В маньчжурском языке слово кулун употребляется в значении «вечное небо», «вечная природа», «вечная земля», «вечный, постоянный». В эвенкийском, эвенском, нанайском, негидальском, ульчском языках производные от корня кул/кол означают «неподвижный, безмолвный» [33, с. 429]. Одно из названий Полярной Звезды - коланду, по всей видимости, связано с ее неподвижным, постоянным положением на небосводе [7, с. 210]. Приведенная интерпретация запевной строки представляется уместной, так как само повествование в рассматриваемом запеве и комментарии информантов Г. М. Василевич уводят нас в мифологически древнюю эпоху. Содержание строки в данном случае следует понимать как «вечное природное начало».

Смысл запевной строки Декур-Декур достаточно сложен для понимания, так как словообразовательное гнездо не может трактоваться однозначно - в тунгусо-маньчжурских языках начальная лексическая пара де встречается во множестве лексем, смысл которых может оказаться уместным по отношению к ранним историческим эпохам. Подробный лингвистический анализ демонстрирует, что применительно к наиболее древней исторической эпохе стадий формирования земли, из существующего лингвистического многообразия в тунгусо-маньчжурских языках могут относиться лишь две лексемы: 1. де-кин (красивый) [36, с. 195]; 2. де-кта - период распускания листьев; хвоя лиственницы, опавшая хвоя лиственницы, лиственница осенью [33, с. 202; 34, с. 186]. Оба значения 
теоретически могут быть применены для обозначения эволюционной стадии. Первая - в виде поэтической характеристики эпохи, что не вписывается в фольклорные традиции обрядовой поэзии эвенков (обрядовые традиции эвенков одной из своих задач имеют наиболее точное описание этнографической или исторической сути ритуального действия). В этой связи попытаемся детально разобрать второй возможный вариант - де-кта, который в большей степени соответствует эвенкийским обрядовым традициям и может указывать на историческую эпоху формирования сибирского ландшафта и распространения флоры на земле (в Сибири). Уточним - суффикс -кта/-ктэ в эвенкийском языке обычно формирует слова, обозначающие ту или иную растительность, в данном случае декта - «хвоя», «лиственница с опавшей хвоей» [33, с. 202]. В целом суффикс -кта/-ктэ является суффиксом многократного вида (по отношению к местам, территории) [8, с. 51]. Следовательно, декур можно понимать как «процесс распространения лиственницы с опадающей хвоей». Историческим периодом, информация о котором могла сохраниться в древнем шаманском запеве, на наш взгляд, является эпоха появления и распространения лиственницы - главного «полезного» дерева в эвенкийском мировоззрении и хозяйственных традициях.

В палеоботанике считается, что распространение современных хвойных пород деревьев происходило в Сибири в связи с глобальным похолоданием, начиная со второй половины третичной эпохи (65-1,8 млн лет назад). Лиственница (larix), являясь одной из самых молодых представительниц хвойных, приобрела новое свойство - способность избавляться от хвои в холодное время года, благодаря чему смогла продвинуться дальше всех других хвойных на север, распространившись по территории всей Сибири. Согласно исследованиям палеоботаники, распространение лиственничных лесов в Сибири происходило в позднем палеолите: «Время формирования слоя 4 соответствует завершающей фазе каргинского потепления. Она характеризуется развитием еловых (с лиственницей) лесов» $[15$, с. 7].

Предполагаем, что запевная строка Декур-декур повествует об эпохе распространения лиственницы современного типа (larix sibirica), в эпоху зырянского оледенения и позднее. Палеоботанические исследования в западной Сибири указывают на распространение лиственницы современного типа в период от 80 до 11 тыс. лет назад [16, с. 193-194]. Схожие результаты демонстрируют генетические исследования лиственницы сибирской на основе анализа митохондриальной ДНК, связывающие распространение вида в условиях последнего ледникового максимума (20-18 тыс. лет назад) [32, с. 163, 166]. Естественно лиственничные леса распространялись и позднее в комбинации с другой древесной растительностью современного сибирского ландшафта, как это происходило в Байкальском регионе в позднеледниковье и голоцене [2].

Интерпретация следующей запевной строки достаточно проста, т.к. в запевных словах Дуннэр-дуннэр отчетливо заметна прямая взаимосвязь со значением дуннэ - земля, местность, страна, почва [36, с. 175]. Однокоренные слова встречаются во всех тунгусо-маньчжурских языках [33, с. 224]. Исходя из последовательности запевных строк обрядового запева, эта строка может символизировать эпоху формирования современного сибирского ландшафта. В этнографических традициях эвенков и их далеких предков - это горная тайга.

Дальнейшая попытка расшифровки древних запевных слов подтверждает вероятность того, что в перечисленных фразах обрядового запева описываются важнейшие этапы эволюции земли и в большей степени сибирского ландшафта. Так, фраза Химир-химир, очевидно, происходит от устаревшего «химипча»- покрываться инеем, льдом [36, с. 555], что может соответствовать эпохе какого-либо оледенения, предположительно, последнего, называемого в науке «сартанским» (25-10,5 тыс. лет тому назад). Как отмечалось ранее, отраженный в зачинах эвенкийских героических сказаний период состояния природы также вполне соотносится с окончанием «сартанского» оледенения [4, с. 49]. Именно отступление последнего ледникового периода повлекло эволюционные изменения климатических условий в Сибири, когда обширные пространства тундры стали постепенно уступать горно-таежному ландшафту [15, с. 44].

Запевная строка Уюр-уюр, по нашему мнению, происходит от эвенкийского слова ую-ми - таять (о снеге) [36, с. 707], что этимологически достаточно точно символизирует окончание эпохи последнего оледенения в Сибири, после которой в силу изменения ландшафтно-климатических условий, распространения новых видов флоры и фауны и, как следствие, адаптации человеческих сообществ к изменениям окружающей среды началось формирование основополагающих культурных признаков ранних этнических формаций Сибири.

Весьма интересной и знаковой для культуры всех тунгусо-маньчжурских народов является этимология запевной фразы Токур-токур - очевидно, ее следует понимать от слова токи - «лось», которое в одинаковом значении встречается во всех диалектах и говорах эвенкийского языка, а также в эвенском, маньчжурском, нанайском, удэгейском, орочском, орокском, негидальском и солонском языках [34, с. 191-192]. По нашему мнению, именно на основе сибирской неолитической кочевой культуры охотников на лося и был сформирован ранний тунгусский культурный комплекс [3].

Строка Аба-аба, по нашему мнению, интерпретируется от тунгусо-маньчжурского корня $A$, обозначающего родственную связь по мужской линии: амтыл (предки по мужской линии), ами, ама (отец), амикан (дед, медведь), акин (дядя) и др. [33, с. 31, 41, 43]. Следует уточнить, что слова с корнем $A$, связанные по значению с мужским родом, мужским началом следует относить к эпохе древней языковой общности, т.к. термины родства, происходящие от корня $A$, встречаются в тюркских (ага, ата, ака, аке и пр.), монгольских (ахай, ахэ) и других весьма отдаленных языках (например, бакском - aita). В маньчжурском языке с корнем $A$ связаны понятия производящей силы, деятельного начала природы, мужского начала природы [Там же, с. 1]. Смысловое значение запевного слова Аба видится во взаимосвязи с древним суффиксом -ба, означающим «место, земля, природа» [6, с. 166]. Следовательно, смысл запевной строки следует связывать с мужским началом природы, в нашем случае, возможно, с развитием патриархальных отношений, либо с культом медведя, сопровождавшего 
этот исторический процесс в мировоззренческих традициях этноса. Известно, что матриархальные традиции древних тунгусов развивались во взаимосвязи с культом прародительницы-лосихи, а патриархальные - с культом предка-медведя [5]. На данную взаимосвязь указывает лексический материал - одно из распространенных названий медведя амака, амикан (иносказательное - «дедушка»), название берлоги абдун, авдун [36, с. 19, 22, 39, 41].

Расшифровка запевной строки Дэрэ-дэрэ видится непростой задачей, т.к. лексемы с корневым ядром дэр встречаются в тунгусо-маньчжурских языках в различных значениях: дэрэ - лицо, южный склон горы; дэри шкура с головы оленя, лося; дэрбэки - шаманский головной убор; головная повязка в виде венца, вышитая бисером; женская головная повязка, вышитая бисером; дэрукэт - играть в коршуна и мн. др. [Там же, с. 190, 191, 192]. Возможно, смысл данной запевной строки является символом завершения формирования сибирского ландшафта: дэр, дэрэ - поверхность земли [33, с. 236]. В то же время возможны иные варианты интерпретации запевных слов, одну из которых мы далее попытаемся представить.

Из всего многообразия, на наш взгляд, наибольшего внимания первоначально заслуживает слово дэрэ/дэрэн/дэјен, которое во всех тунгусо-маньчжурских языках означает: исток, устье реки, начало. При этом в орочском и удэгейском эти же понятия обозначаются так же сокращенным дэ [Там же, с. 238]. Исходя из значения дэ/дэрэ/дэрэн/дэјен, можно предположить, что запевная строка Дэрэ-дэрэ может символизировать начало какого-то важнейшего процесса, например формирование тунгусского культурного комплекса, либо каких-то важнейших древних традиций. Если далее обратиться к лексическому анализу, то обнаруживается определенная взаимосвязь начального дэ со значениями, так или иначе связанными с ритуалом, шаманскими традициями: дэрбэки - шаманская шапка, дэвэ/дэвэксэ - охра, дэвэйдэ - древний коллективный запев, дэвдекин камлание [36, с. 183, 184, 190].

Для расшифровки последней запевной строки обрядового текста вновь обратимся к лексическим материалам, фольклорным и мировоззренческим традициям. Слово дэрбэки (шаманский головной убор, головная повязка), несомненно, происходит от дэри - шкура с головы оленя, лося. Оба слова взаимосвязаны с точки зрения развития шаманских традиций - изначально головные уборы тунгусских шаманов изготавливались из цельной шкуры с головы зверя с рожками. А. И. Мазин, характеризуя символы шаманских атрибутов амурских эвенков, детально проанализировал значение «рогатых» шаманских шапок и других символов, связанных с образом лося, называя их «символом верхнего мира» $[17$, с. 68, 69]. В XIX-XX вв. исследователи зафиксировали традицию использования шаманами некоторых групп эвенков металлических головных уборов с рогами [7, с. 270]. В конце XVII в. И. Идес описал летние головные уборы конных тунгусов Забайкалья: «Вместо шапок они носят шкуру с головы косули с рогами и даже ушами. Такие шапки они особенно надевают, когда идут на охоту, т.к. с помощью их [шапок] обманывают свою будущую добычу, подкрадываясь к ней» [40, p. 31]. Во второй половине XVIII в. головные уборы с рожками среди эвенков были еще широко распространены: «...зимою носятъ шапки изъ звъриныхъ кожъ, а особливо изъ серныхъ головъ, на которыхъ оставляютъ какъ уши, такъ и молодые рога» [10, с. 48]. О традиции ношения конными тунгусами головных уборов, сшитых из шкуры, снятой с головы оленей (с ушами и рогами) упоминал П. С. Паллас [26, с. 331]. В настоящее время традиция ношения головных уборов с рожками сохранилась у современных орочонов Китая, а до XIX в. использовалась мужчинами некоторых эвенкийских родов витимо-олекминской группы. Например, один из крупнейших эвенкийских родов Киндигир по этой причине имел фольклорное наименование «рогатые», а название рода Метакар происходит от эвенкийского мета - шкура с головы копытного животного [36, с. 359].

В фольклоре тунгусо-маньчжурских народов некоторые шаманские традиции маркируются лексемами, производными от дэ. Так, один из ульчских мифов повествует о первопредке Кондолику - хозяине земли, получившем имя Дэрки Дуса, главной задачей которого стал выбор шаманов из числа людей [13, с. 170-171]. В имени мифического персонажа слово дэрки имеет значение «шаманский», «потусторонний», а слово дуса - дух, хозяин. Образ мифологического персонажа ульчей имеет сходство с образами мифологии других тунгусоманьчжурских народов, например, зоо-антропоморфной хозяйки животного мира Кандика у эвенков [18, с. 22]. Реликтовые лексемы от рассматриваемого корневого ядра встречаются в эвенкийском фольклоре. Так, А. Н. Мыреева отмечала, что запевные слова дэрки-дэрки встречаются в эпосе урмийских эвенков [36, с. 191]. В эвенкийском сказании Секак героиня при помощи дочери солнца добирается до Верхнего мира, где встречает девицу Догигчон, которая по известным только ей небесным дорогам провожает прибывших девушек к месту большого праздника. Девушка Верхнего мира обладает запевом Дэги-дэрэкэн, Доги-дэрокон, Дэги-доракан [14, с. 47-48, 204-205]. Первая часть запева девицы Догигчон, как и ее имя, происходит от дэги - птица (в эвенкийской эпической традиции символ принадлежности персонажа к Верхнему миру), вторая часть запева дэрэкэн, дэрокон, доракан, указывает на то, что персонаж обладает шаманскими способностями.

В среде многих групп восточных эвенков самым главным по значимости является запев Дэвэ, дэвэйдэ (охра, красить), происхождение которого связано с неолитическим культом охры у древних тунгусов [4, с. 82-84]. Некоторые исполнители из числа старшего поколения в образовании запевных строк применяют архаический суффикс -дэрку:

Дэвэ, дэвэ, дэвэйдэйэ!

Дэвэрэн-дэрку дэвэйдэйэ...

Слово дэвэрэндэрку состоит из корня дэвэ (охра), суффикса действия -рэн и архаического суффикса -дэрку, который современные исполнители затрудняются точно объяснить, связывая его смысл принадлежностью к обрядовому действию. Как видим, фольклорные и мировоззренческие традиции тунгусо-маньчжурских народов подтверждают наше предположение о смысловой взаимосвязи запевной строки Дэрэ-дэрэ с эпохой становления шаманских традиций у древних тунгусов. 


\section{Заключение}

Подводя итоги краткого исследования, представим обрядовый запев с предположительным значением строк архаического запева:

Пагэй-пагэй! - эпоха зарождения планеты, либо (что заслуживает большего внимания) становления сибирского ландшафта, в частности Байкала;

Кулур-кулур! - мифологически древнее время, природное постоянство;

Декур-декур! - распространение растительности (лиственницы larix sibirica);

Дуннэр-дуннэр! - формирование сибирского ландшафта;

Химир-химир! - эпоха последнего оледенения;

Уюр-уюр! - завершение эпохи оледенения;

Токур-токур! - широкое распространение лося как биологического вида и формирование охотничьей кочевой культуры прототунгусов;

Аба-аба! - развитие традиций отцовского рода, культа медведя;

Дэрэ-дэрэ! - завершение формирования облика сибирского ландшафта, либо начало возникновения шаманских традиций.

Как видим, все слова, представленные в запевных строках, встречаются в разных тунгусо-маньчжурских языках, что свидетельствует об их генезисе в эпоху древней тунгусской общности.

Таким образом, в фольклорных и мировоззренческих традициях эвенков отчетливо просматриваются реликтовые формы знаний древних сообществ об эволюции сибирского ландшафта и человеческого общества на рубеже и в начале голоцена. Привлечение традиций устного народного творчества и этнического мировоззрения в междисциплинарных исследованиях представляет существенные перспективы в решении актуальных проблем современной науки в рамках различных научных специальностей.

\section{Источники | References}

1. Байкальские легенды и предания / сост. Л. Е. Элиасов. Улан-Удэ: Бурятское кн. изд-во, 1984. 256 с.

2. Безрукова Е. В., Летунова П. П., Кулагина Н. В., Шарова О. Г. История природной среды озера Байкал в позднеледниковье и голоцене (на примере пыльцевых записей из болотных экосистем) // Евразия в кайонозое. Статиграфия, палеоэкология, культуры. 2012. № 1. С. 36-48.

3. Варламов А. Н. Образ лося в мировоззрении и фольклоре тунгусо-маньчжурских народов: к вопросу о ранней истории тунгусов // Народы и культуры Северной Азии в контексте научного наследия Г. М. Василевич: тезисы докладов Всероссийской научно-практической конференции, посвященной 125-летию Глафиры Макарьевны Василевич (24-25 сентября 2020 г., г. Якутск). Якутск: Электронное изд-во НБ РС(Я), 2020. С. 95-97.

4. Варламов А. Н. Специфика историзма в фольклоре эвенков. СПб.: Лань, 2018. 308 с.

5. Василевич Г. М. Древнейшие охотничьи и оленеводческие обряды эвенков // Сборник Музея антропологии и этнографии (МАЭ): в 63-х т. Л.: Наука, 1957. Т. 17. С. 151-186.

6. Василевич Г. М. О культе медведя у эвенков // Сборник Музея антропологии и этнографии. Л.: Наука, 1971. T. XXVII. Религиозные представления и обряды народов Сибири в XIX - начале XX века. С. 150-169.

7. Василевич Г. М. Эвенки. Историко-этнографические очерки (XVIII - начало XX в.). Л.: Наука, 1969. 304 с.

8. Василевич Г. М. Эвенкийско-русский диалектологический словарь. М. - Л.: Учпедгиз, 1934. 246 с.

9. Васильев С. А., Березкин Ю. Е., Козинцев А. Г., Пейрос И. И., Слободин С. Б., Табарев А. В. Заселение человеком Нового Света: опыт комплексного исследования. СПб.: Нестор-История, 2015. 680 с.

10. Георги И. Г. Описание всех обитающих в Российском государстве народов и их житейских обрядов, обыкновений, одежд, жилищ, вероисповеданий и прочих достопамятностей: в 4-х ч. СПб.: Императорская Академия Наук, 1799. Ч. 4. О народах монгольских, об армянах, грузинах, индийцах, немцах, поляках и о владычествующих россиянах, с описанием всех наименований козаков, также история о Малой России и купно о Курландии и Литве. 385 с.

11. Гумилев Л. Н. Passionarium. Теория пассионарности и этногенеза. М.: АСТ, 2016. 936 с.

12. Зенин В. Н. Поздний палеолит западно-сибирской равнины: автореф. дисс. ... д. ист. н. Новосибирск, 2003. 60 с.

13. Золотарев А. М. Родовой строй и религия ульчей. Хабаровск: Дальгиз, 1939. 205 с.

14. Исторический фольклор эвенков. Сказания и предания / сост. Г. М. Василевич. М. - Л.: Наука, 1966.400 с.

15. Кривоногов С. К. Стратиграфия и палеогеография Нижнего Прииртышья в эпоху последнего оледенения. Новосибирск: Наука, 1988. 230 с.

16. Лаухин С. А. Палеорастительность и палеоклиматы раннего интерстадиала зырянского оледенения бореальной зоны западно-сибирской равнины // Вестник археологии, антропологии и этнографии. 2008. № 8. С. 188-205.

17. Мазин А. И. Традиционные верования и обряды эвенков-орочонов (конец XIX - начало XX в.). Новосибирск: Наука, 1984. 201 с.

18. Материалы по эвенкийскому (тунгусскому) фольклору / сост. Г. М. Василевич. Л.: Изд-во ин-та народов Севера ЦИК СССР им. П. Г. Смидовича, 1936. 290 с.

19. Мелетинский Е. М. Возникновение и ранние формы словесного искусства // История всемирной литературы: в 9-ти т. / АН СССР; Ин-т мировой лит. им. А. М. Горького. М., 1983. Т. 1. С. 23-52. 
20. Мелетинский Е. М. Первобытное наследие в архаических эпосах // Материалы VII Международного конгресса антропологических и этнографических наук. М.: Наука, 1964. 12 с.

21. Надеждин Н. И. Опыт исторической географии русского мира // Библиотека для чтения. СПб., 1837. Отд. 3. № 6. Т. XXII. Ч. 2. Об исторических трудах в России. С. 28-79.

22. Налепин А. Л. Изучение проблем историзма в американской фольклористике. Критический анализ // Фольклор, проблемы историзма / АН СССР; Институт мировой литературы им. А. М. Горького. М.: Высшая школа, 1988. С. 42-70.

23. Окладников А. П. Неолит и бронзовый век Прибайкалья: историко-археологическое исследование: в 2-х ч. М.-Л.: Изд-во АН СССР, 1950. Ч. I-II. 412 с.

24. Окладников А. П., Мазин А. И. Писаницы бассейна р. Алдан. Новосибирск: Наука, 1979. 152 с.

25. Окладников А. П., Мазин А. И. Писаницы реки Олёкмы и Верхнего Приамурья. Новосибирск: Наука, 1976. 189 с.

26. Паллас П. С. Путешествие по разным провинциям Российского государства Петра Симона Палласа, медицины доктора, натуральной истории профессора, Санкт-Петербургской Императорской Академии Наук и Вольного Экономического общества, Римской Императорской Академии, Королевского Аглинского собрания и Берлинского естествоиспытательного общества члена. СПб.: Императорская Академия Наук, 1788. Ч. 3. Кн. 1. 1772 и 1773 гг. / пер. Василий Зуев. XVI+624 с.

27. Пропп В. Я. Об историзме русского фольклора и методах его изучения // Пропп В. Я. Поэтика фольклора. М.: Лабиринт, 1998. С. 185-208.

28. Пропп В. Я. Фольклор и действительность. Избранные статьи. М.: Наука, 1976. 326 с.

29. Путилов Б. Н. Типология фольклорного историзма // Типология народного эпоса / ред. В. М. Гацак. М.: Наука, 1975. С. $164-181$.

30. Путилов Б. Н. Фольклорный процесс и этническая история народов Сибири и Дальнего Востока // Фольклорное наследие народов Сибири и Дальнего Востока / АН СССР; Науч. совет по фольклору и др.; отв. ред. В. М. Гацак. Горно-Алтайск, 1986. С. 15-22.

31. Сем Т. Ю. Картина мира тунгусов: пантеон (семантика образов и этнокультурные связи): историкоэтнографические очерки. СПб.: Филологический факультет СПбГУ, 2012. 626 с.

32. Семериков В. Л., Ирошников А. И., Ласко М. Структура изменчивости митохондриальной ДНК и послеледниковая история лиственницы Сибирской // Экология. 2007. № 3. С. 163-171.

33. Сравнительный словарь тунгусо-маньчжурских языков: материалы к этимологическому словарю: в 2-х т. / отв. ред. В. И. Цинциус. Л.: Наука, 1975. Т. 1. 672 с.

34. Сравнительный словарь тунгусо-маньчжурских языков: материалы к этимологическому словарю: в 2-х т. / отв. ред. В. И. Цинциус. Л.: Наука, 1977. Т. 2. 992 с.

35. Чипизубов А. В., Смекалин О. П., Имаев В. С. Палеосейсмодислокации и палеоземлетрясения зоны Приморского разлома (оз. Байкал) // Вопросы инженерной сейсмологии. 2015. Т. 42. № 3. С. 5-19.

36. Эвенкийско-русский словарь / сост. А. Н. Мыреева. Новосибирск: Наука, 2004. 798 с.

37. Эвенкийско-русский словарь / сост. Г. М. Василевич. М.: Гос. изд-во иностранных и национальных словарей, 1958. $576 \mathrm{c.}$

38. Элиасов Л. Е. Русский фольклор Восточной Сибири: в 3-х т. Улан-Удэ: Тип. Министерства культуры БАССР, 1960. Т. ІІ. Народные предания. 480 с.

39. Fewkes J. W. Tussayan Migration Traditions // Nineteenth Annual Report of Bureau of American Ethnology. Washington, 1900. Part 2. P. 573-633.

40. Ides E. I. Three Years Travels from Moscow Over-land to China: thro Great Ustiga, Siriania, Permia, Sibiria, Daour, Great Tartary, \&c. to Peking. L.: Printed in Dutch by the Direction of Burgomaster Witzen, 1706. 210 p.

\section{Информация об авторах | Author information}

RU Варламов Александр Николаевич ${ }^{1}$, д. филол. н.

${ }^{1}$ Институт гуманитарных исследований и проблем малочисленных народов Севера

Сибирского отделения Российской академии наук, г. Якутск

EN Varlamov Alexander Nikolaevich ${ }^{1}$, Dr

${ }^{1}$ Institute for Humanities Research and Indigenous Studies of the North

of the Siberian Branch of the Russian Academy of Sciences, Yakutsk

${ }^{1}$ ataki2006@yandex.ru

\section{Информация о статье | About this article}

Дата поступления рукописи (received): 18.08.2021; опубликовано (published): 30.09.2021.

Ключевые слова (keywords): фольклор эвенков; эвенкийский шаманизм; обряд Икэнипкэ; эволюция сибирского ландшафта; историзм фольклора; Evenk folklore; Evenk shamanism; “Ikenipke” ritual; Siberian landscape evolution; historicism of folklore. 